\title{
Hodnocení individuální míry pohybové aktivity dotazníky IPAQ a Wellness Inventory: prípadová studie
}

\section{Measuring Individual Physical Activity with IPAQ and Wellness Inventory questionnaires: Case study}

\author{
Jana Stará, Tomáš Vespalec
}

Fakulta sportovních studií, Masarykova univerzita, Brno

\begin{abstract}
Abstrakt
Dotazníková šetřeníjsou poměrně rychlým, levným a efektivním způsobem získávání dat, a bývají proto využívána pro sběr populačních dat jako základu pro návrh intervenčních programů, a následně také k individuální práci s klientem. Kvantitativní podstata dotazníkových metod však nepokrývá kvalitativní charakteristiky individuální změny lidského chování, což dotazníky limituje co do interpretace individuální změny chování jedince. Tato prípadová studie porovnávala dva dotazníkové nástroje International Physical Activity Questionnaire (IPAQ) a Wellness Inventory (WI) s cílem príbližit jejich výhody, nevýhody a schopnost reflektovat kvalitativní faktory ovlivňující aktuální míru pohybové aktivity jedince. IPAQ byl potvrzen jako nástroj sledující objektivní množství pohybové aktivity s limity při měření individuální změny. Naopak WI více sleduje subjektivní hodnocení míry pohybové aktivity jako jedné ze sledovaných dimenzi a je více zatižen subjektivním zkreslením odpovědí. Ani jeden z nástrojů prímo nereflektoval vnější faktory (roční období, zdravotní stav, změna zaměstnání, motivace), přičemž WI byl k těmto vlivům citlivější. Oba nástroje Ize použít při sledování změny pohybové aktivity a pro zvýšení schopnosti interpretovat individuální změny. Doporučujeme je doplnit dalšími instrumentálními a kvalitativními metodami.
\end{abstract}

\begin{abstract}
Questionnaire surveys are relatively quick, cheap and effective way of obtaining data and as such are used as a basis for designing intervention programs, and consequently also in individual work with a client. The quantitative nature of questionnaire method, however, does not cover the qualitative characteristics of individual changes in behavior and as such is limited as to the interpretation of individual behavior changes. This case study compared two questionnaire instruments - International Physical Activity Questionnaire (IPAQ) and Wellness Inventory (WI) in order to explain their advantages and disadvantages, and the ability to reflect the qualitative factors affecting the current level of physical activity of individuals. IPAQ was confirmed as a tool for monitoring the objective amount of physical activity with limited capacity for measuring individual changes. Conversely, WI focuses more on the subjective evaluation of the level of physical activity as one of the examined dimensions and is more burdened by subjective bias. Neither of the instruments directly reflected external factors (seasons, health, job change, motivation), whereas WI has been more sensitive to these influences. Both tools can be used to monitor changes in physical activity. To enhance the ability to interpret individual change it is recommended to supplement other instrumental and qualitative methods.
\end{abstract}

Klíčová slova: IPAQ, Wellness Inventory, měření pohybové aktivity, zdravýživotní styl, lidské chování

Keywords: IPAQ, Wellness Inventory, measurement of physical activity, healthy lifestyle, behavior change 


\section{ÚVOD}

Dostatek pohybové aktivity patř́i mezi základní stavební kameny zdravého životního stylu, přičemž hypokineze jako nedostatečná míra pohybové aktivity je jednou z nejčastějších charakteristik životního stylu dnešní populace (Hendl \& Dobrý, 2011; Stackeová, 2009). Tento trend je na př́kladu české populace podrobně vědecky popsán napřič věkovými skupinami (Frömel, Chmelík, Nykodým, \& Et, 2007; Máček \& Máčková, 2013; Matoulek, Svačina, \& Lajka, 2014; Sigmundová, Sigmund, Hamř́ík, Kalman, \& Frömel, 2014).

Existují mnohé metodiky měření míry pohybové aktivity, přičemž se zpravidla opírají o doporučenou míru aktivního pohybu a danou intenzitu doporučenou Světovou zdravotnickou organizací. Na národní úrovni bývají doporučení upravena pro danou populaci (Kahlmeier et al., 2015).

Sebehodnotící dotazníky patři mezi nejčastější kvantitativní metody měření pohybové aktivity (Castillo-Retamal \& Hinckson, 2011; Westerterp, 2009). Jednotlivé nástroje se liší podle sledovaných proměnných (např. typ pohybové aktivity, její délka či frekvence), měřicích jednotek (napřr. čas či kalorie), různé jsou charakteristiky měřených dat (např. zda se jedná o dlouhodobě vykonávané aktivity či výhradně aktuální aktivity) či způsoby sběru dat (např. dotazníky vyplňované tužkou na papíře, pomocí počítače či interview) (Sylvia, Bernstein, Hubbard, Keating, \& Anderson, 2014).

Princip sebehodnotících dotazníkủ je založen na respondentově schopnosti si zpětně vybavit své aktivity ve sledovaném časovém úseku, zpravidla týden nebo měsíc zpětně. Jako takové podléhají určité míře zkreslení a vykazují nízkou míru validity a reliability (Shephard, 2003). Proto se tyto subjektivní metody zdvojují měřením objektivními nástroji, jako jsou akcelerometry, pedometry či mobilní aplikace (Innerd et al., 2015; Rääsk et al., 2015). Objektivní nástroje udávají podrobnější údaje s různou mírou validity (An, Jones, Kang, Welk, \& Lee, 2016) a při porovnání se sebehodnotícími dotazníky vykazují hodnoty jak vyšší, tak nižší, což poukazuje na problém se spolehlivostí těchto metod i případnou korekturou jimi naměřených dat (Prince et al., 2008; Westerterp, 2009).

Druhým omezením kvantitativních metod sběru dat je jejich schopnost sledovat individuální změny a kvalitativní podstatu lidského chování a kontextu, ve kterém změna probíhá. Pedersen et al. (2009) uvádí, že individuální vzorce pohybové aktivity se liší den ode dne, a existuje pouze omezené poznání o tom, kolik dní objektivního měření je třeba pro získání dostatečné míry reliability. Gabrys et al. (2015) uvádí, že pro hodnocení habituální pohybové aktivity je třeba provádět měření aspoň 7 po sobě jdoucích dní včetně víkendu. Podle Corder et al. (2009), kteří se ve svém výzkumu zaměřili na věkovou skupinu 4-17 let, jsou sebehodnotící dotazníky validní pro sledování skupinové změny, avšak vykazují chyby při určování individuálních změn, což potvrzují i další výzkumy (Bonnefoy et al., 2001; Conway, Irwin, \& Ainsworth, 2002; Washburn, Jacobsen, Sonko, Hill, \& Donnelly, 2003).

Dotazníky jako svou podstatou kvantitativní nástroje sběru dat nepokrývají psychologické motivační faktory, které tvoří dynamiku lidského chování. Proto se nabízí námitka, že není v možnostech těchto metod a snad ani v jejich cílech sledované lidské chování blíže pochopit či hlouběji interpretovat (Carrasco \& Lucas, 2015). Shephard (2003) hodnotí dotazníková data jako nedostatečná pro podrobnější interpretaci co do dávkování pohybové aktivity či jejich vlivů na zdraví jedince. Přesto tento autor vidí možné východisko ve zpřesnění standardizovaných nástrojů, aby sledovaly také aktivity s nízkou intenzitou, které jsou typické pro sedavé společnosti. Navrhuje také bliže specifikovat biologickou podstatu termínů lehkého, stř̌edně těžkého a těžkého pohybu.

Po stránce praktického využití jsou standardizované dotazníky často východiskem pro návrh intervenčních programů zaměřených na změnu chování (Hendl \& Dobrý, 2011) a jsou také využívány při individuální práci na změně životního stylu. $\mathrm{V}$ takovýchto př́padech je na místě 
zvýšená pozornost k uvedeným limitům standardizovaných dotazníků, zejména pokud se jedná o intervence zaměřené obecněji na podporu zdravého životního stylu, a nejen výhradně na úpravu míry aktivního pohybu v životě jednotlivce.

Cílem této práce bylo na príípadové studii porovnat data ze dvou nástrojů - dotazníku IPAQ (International Physical Activity Questionnaire) a WI (Wellness Inventory), a odpovědět na otázku, které výhody a nevýhody jednotlivé metody přinášejí a jak reflektují kvalitativní faktory ovlivňující aktuální míru pohybové aktivity jedince.

\section{METODIKA}

Charakteristika účastníků. Tato případová studie byla provedena na 5 respondentech, 3 mužích a 2 ženách ve věku 27-30 let. Jednalo se o vysokoškoláky - aktivní studenty či čerstvé absolventy, kteří se na jaře 2015 účastnili 13týdenní intervence podporující zdravý životní styl dle metodiky Wellness Inventory (Travis \& Ryan, 2004). Výběr účastníků byl na principu dobrovolnosti a dostupnosti, přičemž časová náročnost intervence limitovala celkovou velikost zkoumaného vzorku.

Dotazníková data byla sbírána před začátkem intervence, po jejím ukončení a 6 měsíců poté. Použity byly následující dva dotazníky doplněné otevřenou otázkou, ve které respondenti vyjadřovali své postřehy, komentovali pocitované změny či životní události, které mohly mít vliv na sledované proměnné.

\section{IPAQ (International Physical Activity Questionnaire)}

V tomto výzkumu byla použita krátká verze IPAQ dotazníku, který byl vyvinut pro sledování pohybové aktivity na národní úrovni (Bauman et al., 2009; Craig et al., 2003). Respondenti odpovídají na otázky kolik času a v kolika dnech uplynulého týdne trávili intenzivními a středně zatěžujícími pohybovými aktivitami prováděnými v zaměstnání, jako součást domácích prací, na zahradě, prí přemístování se z místa na místo a ve svém volném čase při rekreaci, cvičení či sportu. Dále je sledována také chůze a čas strávený sezením.

Výsledný počet MET-minut/týden je následně škálován na nízkou, střední a vysokou míru pohybové aktivity dle pohybových doporučení. Čas strávený sezením není v závěrečném výpočtu zahrnut.

\section{Wellness Inventory (WI)}

Wellness Inventory (Travis \& Ryan, 2004) bylo vyvinuto jako nástroj pro individuální práci na změně životního stylu. Dotazník sleduje pohybovou aktivitu jako jednu ze dvanácti dimenzí wellness. Respondenti odpovídají na škále $0-4$ nakolik subjektivně souhlasí s danými tvrzeními:

1. Vím, kolik pohybu mé tělo potřebuje a snažím se tyto potřeby naplňovat.

2. Rád objevuji nové a účinné formy cvičení a pohybu pro lepší zdraví a pohodu.

3. Baví mě protahování, pohyb a rozvoj mého těla.

4. Denně se oddávám aspoň 15 minutám intenzivní fyzické aktivity.

5. Pokud mohu, místo ježdění výtahem chodím po schodech.

6. Místo jízdy autem preferuji na krátké vzdálenosti pěší chůzi nebo jízdu na kole.

7. Alespoň třikrát týdně se věnuji aerobním aktivitám (např. běh, cyklistika, plavání, rychlá chůze nebo jiné intenzivní fyzické cvičení), a to alespoň 20 minut v kuse.

8. Vybrané formě strečinku nebo protahování (např. józe) se věnuji 20-30 minut alespoň třikrát týdně.

9. Věnuji se formě cvičení, která spojuje prvky dýchání, pohybu a vnímání těla.

10. Při sportu zažíám povznesené stavy vědomí (dostávám se do tzv. zóny). 
Výsledná průměrná hodnota odpovědí respondenta ukazuje úroveň dané dimenze, přičemž celý nástroj výsledky nijak dále nehodnotí, spíše respondentovi poskytuje přímou zpětnou vazbu na jeho zdraví z celostního pohledu (Palombi, 1992).

\section{VÝSLEDKY}

\section{Hodnocení dle IPAQ:}

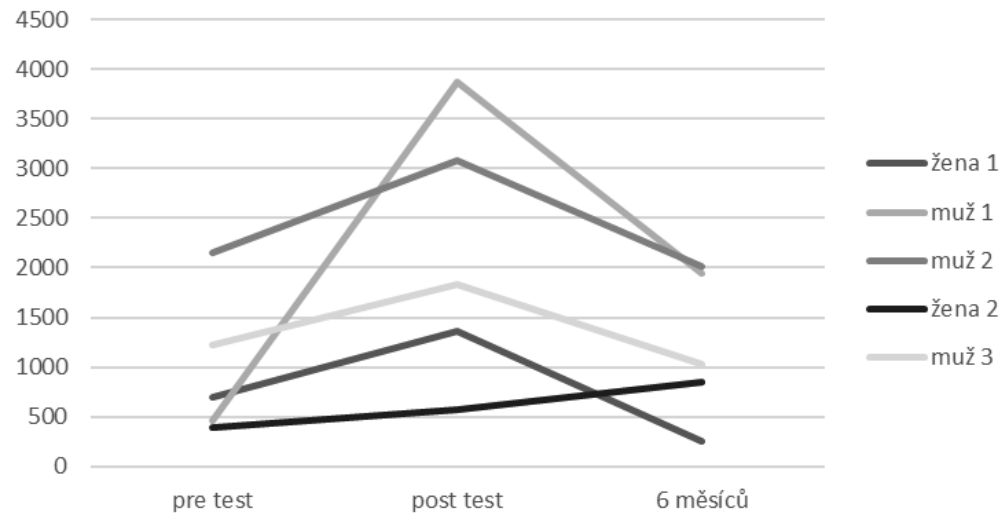

Obr. 1: Hodnocení pohybové aktivity dle I (zdroj: vlastní)

Na počátku intervence měli dva účastníci (muž 1 a žena 2) nízkou míru pohybové aktivity (méně než 600 MET-minut/týden) a ostatní byli v rozmezí hodnot pro střední míru pohybu (rozmez 600-3000 MET-minut/týdně). Při měření post testem se všichni měření respondenti zlepšili ve svých hodnotách, přičemž muž 1 a muž 2 splnili kritéria pro vysokou míru pohybové aktivity. Pouze žena 2 zůstala i přes mírné zlepšení v úrovni nízké aktivity. Po 6 měsících od ukončení intervence většině sledovaných účastníků míra pohybové aktivity opět poklesla, ve třech případech (muž 2 , muž 3 a žena 1 ) dokonce pod úroveň prvního měření a pouze žena 2 se v uváděných hodnotách zlepšila $\mathrm{z}$ mírné do střední hladiny pohybové aktivity.

$\mathrm{Z}$ hlediska věcné významnosti měřené Cohenovým $\mathrm{D}$ byly změny mezi měřeními velké (2,28 mezi prvním a druhým měřením a 1,75 mezi druhým a třetím měřením), avšak v porovnání prvního a třetího měření je změna malá (Cohenovo $\mathrm{D}=0,32$ ). To může naznačovat, že intervence byla co do dlouhodobé úpravy pohybových vzorců svých účastníků neúspěšná. 


\section{Hodnocení dle Wellness Inventory}

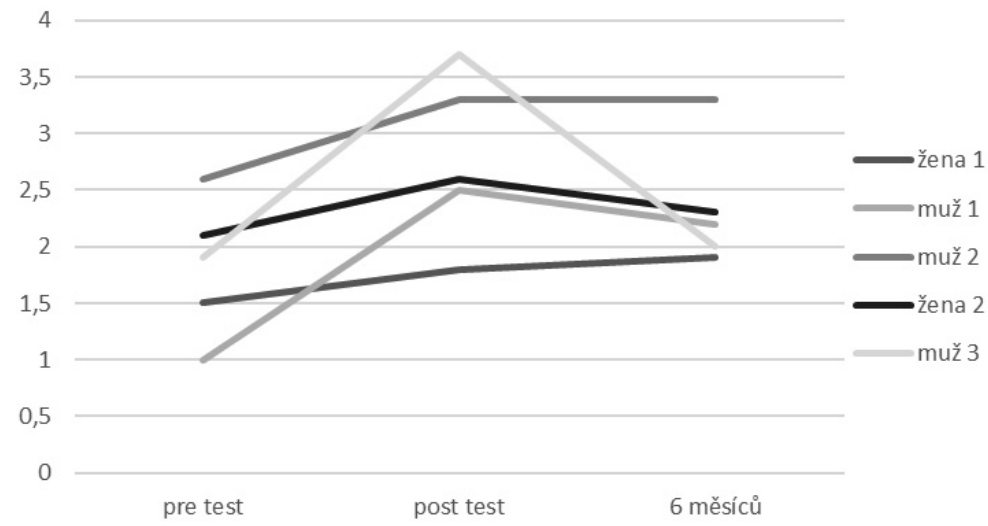

Obr. 2: Hodnocení pohybové aktivity dle Wellness Inventory (zdroj: vlastní)

Měření dle WI také reflektuje nárůst měřených hodnot po ukončení intervence (post testu) u všech účastníků. Při porovnání s měřením dle IPAQ však ukazuje menší klesající tendenci po 6 měsících od intervence. U dvou účastníků (žena 1 a muž 2) byl zaznamenán nárůst i po 6 měsících od ukončení intervence.

$\mathrm{Z}$ hlediska měření věcné významnosti došlo mezi prvním a druhým měřením k velkému rozdílu (Cohenovo $\mathrm{D}=1,43$ ), změna mezi druhým a třetím měřením byla střední (Cohenovo $\mathrm{D}=0,68$ ), avšak rozdíl mezi prvním a třetím měřením zůstal velký (Cohenovo $\mathrm{D}=0,9$ ), což by mohlo svědčit o úspěšnosti a udržitelnosti vlivu intervenčního programu.

\section{Individuální hodnocení účastníků:}

Žena 1 měla dle IPAQ nejvýraznější pokles při měření po 6 měsících, a to pod úroveň pretestu. To bylo způsobeno aktuálním onemocněním před závěrečným měřením. Dle WI však žena 1 indikovala postupný nárůst ve všech třech měřeních, což naznačuje, že subjektivní měření může jít za míru aktuálního pohybu, aktuální situace a sleduje hladinu postojů a záměrů, kdy byla respondentka se svou mírou pohybu spokojená, přestože byla její reálná PA krátkodobě negativně ovlivněna nemocí.

Žena 2 dle dotazníku IPAQ dosahovala nejnižších hodnot s mírným nárůstem množství pohybové aktivity při posledním měření, kdy ostatní respondenti dle uváděných hodnot klesali. Dle WI respondentka uváděla průměrné a stabilní hodnoty ve všech třech měřeních. Respondentka se v době intervence potýkala s chronickými zdravotní problémy a vysokou pracovní zátěží. V daném kontextu může i uváděné mírné zlepšení a vytvoření základního pohybového návyku na konci měření indikovat vědomý a $\mathrm{v}$ daném kontextu jediný možný pokrok.

Muž 1 dle IPAQ vykázal největší změny, a to jak nárůstu, tak i poklesu pohybové aktivity. Tento trend se u něj se opakoval i dle WI, avšak s pouze mírným poklesem hodnot mezi posledními dvěma měřeními. Změna mezi prvním a druhým měřením byla dána odchodem ze zaměstnání, kdy muž 1 získal mnohem více času pro pohybové aktivity, které jinak zanedbával. Při měření po 6 měsících již pracoval v novém zaměstnání a vymezil si ve svých dnech více prostoru na pohyb, jelikož to bylo jedno z témat, na kterých chtěl dlouhodobě pracovat. To se mu dle jeho slov „částečně dařilo“, a proto dosahoval menšího poklesu v závěrečném měření dle WI než dle IPAQ.

Muž 2 pravidelně aktivně silově trénoval a od prvního měření přidal do svých aktivit více času tráveného středně zatěžujícím pohybem. Zajímavá dle jeho slov byla právě „rovina vědomého pohybu“, která byla sledována při WI měření. Ta zůstala na obdobné výši i po 6 měsících, přes- 
tože aktuální míra jeho pohybu dle IPAQ sledovala obecný trend nárůstu po intervenci a poklesu po 6 měsících od jejího skončení.

Muž 3 dosahoval průměrných hodnot v měření dle IPAQ, kdy jeho hodnoty sledovaly trend nárůstu a poklesu, přičemž dle WI byla jeho změna nejvýraznější ze všech respondentů - s vysokým nárůstem a poklesem na hladinu počátečních hodnot. Muž 3 začal aktivně běhat a $\mathrm{k}$ tomu dělal doprovodná posilovací cvičení. Běh lze označit za sport vysoce závislý na vnějších podmínkách, které byly v době posttestu (léto) příznivé. Naopak v době pretestu a testu po 6 měsících, které probíhaly v zimním období, respondent označil vnější podmínky za demotivující.

Syntézou výše uvedených dat došli autoři k následujícím poznatkům:

1. Oba dotazníky jsou jednoduché na administraci. IPAQ dotazník ve své krátké verzi zahrnuje pouze 7 stručných otázek, WI při hodnocení všech dimenzí má 120 otázek. Oba dotazníky byli respondenti schopni vyplnit samostatně po předání základních instrukcí. Vyplnění WI znamená větší časovou zátěž, vyžaduje vyšší vstupní motivaci respondentů. Oba dotazníky jsou ohroženy subjektivním zkreslením uváděných odpovědí. Ani jeden z nástrojů nepoužívá kontrolní otázky odhalující míru lži či dalši skrytou kontrolu.

2. Oba dotazníky reflektovaly trend nárůstu pohybové aktivity v době ukončení intervence a jeho pokles po 6 měsících, což odpovídá obecně známým a pozorovaným trendům. Tento zjevný fakt byl ovlivněn kvalitativními podmínkami - aktuálním zdravotním stavem (žena 1 a žena 2), pracovním vytížením (muž 1 , žena 2 ) a ročním obdobím, ve kterém bylo měření prováděno (muž 3). Uvedené proměnné ani jeden z nástrojů při měření nezohledňuje, přičemž dotazník WI tyto změny reflektoval více než IPAQ. K uvedeným limitujícím faktorům subjektivního měření pohybové aktivity např́iklad další autoři přidávají faktory věku, tělesné váhy či hodnocení třetí osobou (Corder et al., 2009; Rääsk et al., 2015).

3. Oba dotazníky lze statisticky zpracovat, jejich výsledky se liší. Dle statistického zpracování naměřených skupinových dat byla intervence podle dotazníku IPAQ neúspěšná, jelikož nebyla prokázána udržitelnost dosažených změn míry pohybové aktivity. Naopak dle WI byla indikovaná změna po intervenci v částečné míře udržena i 6 měsíců od ukončení. Rozdílný charakter měřených dat, kdy IPAQ sleduje čas trávený pohybem ve vymezeném časovém úseku jednoho týdne a WI sleduje subjektivní hodnocení obecně formulovaných tvrzení o pohybové aktivitě v nespecifikovaném časovém období, napovídá o jiné kvalitě výsledků. IPAQ poskytuje data objektivního charakteru o množství pohybové aktivity, WI data kvalitativního charakteru o subjektivním hodnocení, postojích a motivacích $\mathrm{k}$ pohybu.

4. Oba dotazníky je vhodné použít v různých fázích změny chování jedince (Prochaska \& DiClemente, 1982). Při individuální práci s klientem lze měřená data využít jako vstupní diagnostiku výchozího stavu. WI je následně vhodnější v úvodních fázích, kdy se klient na změnu připravuje nebo ji plánuje a je třeba podnítit jeho vnitřní motivaci. IPAQ je vhodnější v následujících fázích, kdy se změna již projevuje ve fyzickém chování jedince a její měření napomáhá udržet motivaci a sledovat pokrok. Jelikož je proces změny lidského chování cyklický, je vhodné tyto metody kombinovat.

5. Dotazníky je vhodné kombinovat s dalšími metodami. Rozšíření dotazníkového šetření o kvalitativní otevřenou otázku pomohlo a usnadnilo interpretaci naměřených dat a jejich kontextu. Podobně se jako vhodné jeví doplnění dotazovacích metod o instrumentální měření pomocí např. akcelerometrů, pedometrů či sporttesterů. Výhoda objektivního a relativně přesného 
kvantitativního měření je však vykoupena vyšší finanční a administrativní náročností takového měření. Navíc přes velký pokrok v této oblasti stále neexistují zcela spolehlivé algoritmy, které by zajistily přesné a zcela automatické rozpoznávání typu pohybu.

\section{DISKUSE}

Tato př́ípadová studie byla provedena na malé skupině respondentů a možnosti vyvozovat z ní obecné závěry jsou tímto faktem limitované. Přesto uvedená tvrzení na úrovni pilotní studie ilustrují skutečnosti vstupující do procesu měření pohybové aktivity a nastiňují možnosti pro následné zkoumání. Předpokládáme však, že výzkum na rozsáhlejší populační skupině by mohl přinést podobné závěry, případně námi nastíněné trendy zpřesnit.

Je třeba také zdůraznit, že dotazník IPAQ byl od svého počátku navržen jako vědecký nástroj pro sledování populačních dat a sami autoři jej nepovažují za nástroj určený k posuzování individuálních změn. Přesto je tento nástroj pro svou jednoduchost v praxi často používán v práci $\mathrm{s}$ individuálními klienty. Cílem tohoto článku nebylo propagovat IPAQ pro individuální práci, nýbrž poukázat na jeho prrípadné limity, pokud je tak využíán.

\section{ZÁVĚRY}

Dotazníky měřící pohybovou aktivitu se zabývají behaviorální složkou lidského chování, zda se daný jedinec fyzicky pohybuje či ne. Prince et al. (2008) zdůrazňuje, že přesné měření je důležité pro hodnocení stávající míry pohybové aktivity a jejích změn, a také pro hodnocení efektivity intervencí zaměřených na podporu aktivního pohybu. Tento výzkum nastiňuje, že při intervencích zaměřených na zvýšení kvality či „zdravotní nezávadnosti“ životního stylu nejsou objektivně měřená kritéria jedinou proměnnou, která určuje a ovlivňuje účinnost intervence.

V tomto výzkumu byly sledovány výhody a nevýhody dotazníků IPAQ a WI a jejich schopnost reflektovat kvalitativní faktory ovlivňující aktuální míru pohybové aktivity jedince. Při porovnání dat naměřených těmito metodami bylo dosaženo následujících závěrů:

1. IPAQ je krátký dotazník s jednoduchou administrací, který poskytuje objektivní data o míře pohybové aktivity hodnocené v souladu s pohybovými doporučeními. Bliže však nepokrývá individuální kontext probíhající změny chování měřeného jedince. Je tedy vhodný spíše k hodnocení skupinových změn.

2. WI je rozsáhlý dotazník, který zachycuje subjektivní hodnocení, postoje a motivace daného jedince ve vztahu k pohybové aktivitě. Jeho omezením je náročnější vyplnění a subjektivní zkreslení odpovědí.

3. Ani jeden z dotazníků přímo nesleduje vlivy limitujících faktorů (roční období, zaměstnání, zdravotní stav, motivace), přičemž WI je k těmto vlivům citlivější.

4. Vzhledem $\mathrm{k}$ charakteru změny lidského chování je vhodné dotazníky používat cíleně při vstupní diagnostice a odpovídajících fázích změny, kdy WI je vhodnější při úvodní motivaci klienta ke změně a IPAQ pro monitoring již probíhající změny. 


\section{Závěry pro praxi}

Dotazník jako metoda základního sběru informací o míře pohybové aktivity sledovaného jedince je jednoduchý nástroj, který má své výhody ve snadné administraci, nízkých finančních nákladech a stručné informaci o aktuálním stavu daného jedince. Vzhledem k limitům dotazníkové metody je však vhodné vnímat data pohybových dotazníků s odstupem, ne jako diagnózu.

Stěžejní je přitom základní záměr pohybové intervence nebo účel dotazníkového šetření. Je-li cílem zvýšení trénovanosti jedince, jsou objektivní metody vhodnější, ideálně doplněné o instrumentální měření. Pokud se jedná o úpravu životního stylu jedince, subjektivní metody poskytují obsáhlejší informace, a je vhodné je dále doplnit kvalitativními metodami jako jsou rozhovor a individuální práce.

\section{Literatura}

An, H.-S., Jones, G. C., Kang, S.-K., Welk, G. J., \& Lee, J.-M. (2016). How valid are wearable physical activity trackers for measuring steps? European Journal of Sport Science, O(0), 1-9. https://doi.org/10.1080/17461391.2016.1255261

Bauman, A., Bull, F., Chey, T., Craig, C. L., Ainsworth, B. E., Sallis, J. F., ... Pratt, M. (2009). The International Prevalence Study on Physical Activity: results from 20 countries. International Journal of Behavioral Nutrition and Physical Activity, 6, 21. https://doi.org/10.1186/1479-5868-6-21

Bonnefoy, M., Normand, S., Pachiaudi, C., Lacour, J. R., Laville, M., \& Kostka, T. (2001). Simultaneous Validation of Ten Physical Activity Questionnaires in Older Men: A Doubly Labeled Water Study. Journal of the American Geriatrics Society, 49(1), 28-35. https://doi.org/10.1046/j.1532-5415.2001.49006.x

Carrasco, J.-A., \& Lucas, K. (2015). Workshop Synthesis: Measuring Attitudes; Quantitative and Qualitative Methods. Transportation Research Procedia, 11, 165-171. https://doi.org/10.1016/j.trpro.2015.12.014

Castillo-Retamal, M., \& Hinckson, E. A. (2011). Measuring physical activity and sedentary behaviour at work: a review. Work (Reading, Mass.), 40(4), 345-357. https://doi.org/10.3233/WOR-2011-1246

Conway, J. M., Irwin, M. L., \& Ainsworth, B. E. (2002). Estimating energy expenditure from the Minnesota Leisure Time Physical Activity and Tecumseh Occupational Activity questionnaires - a doubly labeled water validation. Journal of Clinical Epidemiology, 55(4), 392-399. https://doi.org/10.1016/S0895-4356(01)00497-8

Corder, K., van Sluijs, E. M. F., Wright, A., Whincup, P., Wareham, N. J., \& Ekelund, U. (2009). Is it possible to assess free-living physical activity and energy expenditure in young people by self-report? The American Journal of Clinical Nutrition, 89(3), 862-870. https://doi.org/10.3945/ajcn.2008.26739

Craig, C. L., Marshall, A. L., Sjöström, M., Bauman, A. E., Booth, M. L., Ainsworth, B. E., ... Oja, P. (2003). International physical activity questionnaire: 12-country reliability and validity. Medicine and Science in Sports and Exercise, 35(8), 1381-1395. https://doi.org/10.1249/01.MSS.0000078924.61453.FB

Frömel, K., Chmelík, F., Nykodým, J., \& Et, A. (2007). Pohybová aktivita české mládeže: koreláty intenzivní pohybové aktivity. Česká kinantropologie. Retrieved from https://is.muni.cz/publication/765765

Gabrys, L., Thiel, C., Tallner, A., Wilms, B., Müller, C., Kahlert, D., ... Vogt, L. (2015). Akzelerometrie zur Erfassung körperlicher Aktivität. Sportwissenschaft, 45(1), 1-9. https://doi.org/10.1007/s12662-014-0349-5

Hendl, J., \& Dobrý, L. (2011). Zdravotní benefity pohybových aktivit: monitorování, intervence, evaluace (Vyd. 1). Praha: Karolinum.

Innerd, P., Catt, M., Collerton, J., Davies, K., Trenell, M., Kirkwood, T. B. L., \& Jagger, C. (2015). A comparison of subjective and objective measures of physical activity from the Newcastle 85+ study. Age And Ageing, 44(4), 691-694. https:// doi.org/10.1093/ageing/afv062

Kahlmeier, S., Wijnhoven, T. M. A., Alpiger, P., Schweizer, C., Breda, J., \& Martin, B. W. (2015). National physical activity recommendations: systematic overview and analysis of the situation in European countries. BMC Public Health, 15, $133-133$. https://doi.org/10.1186/s12889-015-1412-3

Máček, M., \& Máčková, J. (2013). Pohybová aktivita a dětská obezita. Medicina Sportiva Bohemica et Slovaca, 22(2), 96-102.

Matoulek, M., Svačina, Š., \& Lajka, J. (2014). Pohybová aktivita a obezita v ČR 2000-2013. Physical Activity and Obesity in Czech Republic in 2000-2013., 23(1), 8-9.

Palombi, B. J. (1992). Psychometric Properties of Wellness Instruments. Journal of Counseling \& Development, 71(2), $221-225$. https://doi.org/10.1002/j.1556-6676.1992.tb02204.x

Prince, S. A., Adamo, K. B., Hamel, M. E., Hardt, J., Connor Gorber, S., \& Tremblay, M. (2008). A comparison of direct versus self-report measures for assessing physical activity in adults: a systematic review. The International Journal of Behavioral Nutrition and Physical Activity, 5, 56. https://doi.org/10.1186/1479-5868-5-56

Prochaska, J. O., \& DiClemente, C. C. (1982). Transtheoretical therapy: Toward a more integrative model of change. Psychotherapy: Theory, Research \& Practice, 19(3), 276-288. https://doi.org/10.1037/h0088437

Rääsk, T., Lätt, E., Jürimäe, T., Mäestu, J., Jürimäe, J., \& Konstabel, K. (2015). Association of Subjective Ratings to Objectively Assessed Physical Activity in Pubertal Boys with Differing Bmi. Perceptual And Motor Skills, 121(1), 245-259. https:// doi.org/10.2466/10.03.PMS.121c13x7 
Shephard, R. J. (2003). Limits to the measurement of habitual physical activity by questionnaires. British Journal of Sports Medicine, 37(3), 197-206; discussion 206.

Sigmundová, D., Sigmund, E., Hamřík, Z., Kalman, M., \& Frömel, K. (2014). Trendy ve vývoji pohybového chování obyvatel České Republiky. Trends in Physical Behaviour in Czech Inhabitans., 23(3), 105-108.

Stackeová, D. (2009). Zdravotní benefity pohybových aktivit : východisko pro tvorbu doporučení pro mládež a dospělé. Tělesná výchova a sport mládeže: Odborný časopis pro učitele, trenéry a cvičitele, 75(1). Retrieved from http://katalog. npmk.cz/documents/248631

Sylvia, L. G., Bernstein, E. E., Hubbard, J. L., Keating, L., \& Anderson, E. J. (2014). A Practical Guide to Measuring Physical Activity. Journal of the Academy of Nutrition and Dietetics, 114(2), 199-208. https://doi.org/10.1016/j.jand.2013.09.018

Travis, J. W., \& Ryan, R. S. (2004). Wellness workbook: How to achieve enduring health and vitality. Berkeley: Celestial Arts.

Washburn, R., Jacobsen, D., Sonko, B., Hill, J., \& Donnelly, J. (2003). The validity of the Stanford seven-day physical activity recall in young adults. Medicine and science in sports and exercise, 35(8), 1374-1380.

Westerterp, K. R. (2009). Assessment of physical activity: a critical appraisal. European Journal of Applied Physiology, 105(6), 823-828. https://doi.org/10.1007/s00421-009-1000-2

\section{Kontakt na autora:}

jana.stara@mail.muni.cz 